\title{
Random Pattern Rotation Flaps in the Treatment of Advanced Sacrococcygeal Pilonidal Disease with Damaged Skin Structure
}

\author{
Hasan Ediz Sıkar, Kenan Çetin
}

Department of General Surgery, Dr. Lütfi Kırdar Kartal Training and Research Hospital, İstanbul, Turkey

Submitted: 28.03.2019 Accepted: 07.05.2019

Correspondence: Hasan Ediz Sıkar, Dr. Lütfi Kırdar Kartal Eğitim ve Araştırma Hastanesi, Genel Cerrahi Kliniği, İstanbul, Turkey E-mail: hasan.sikar@me.com

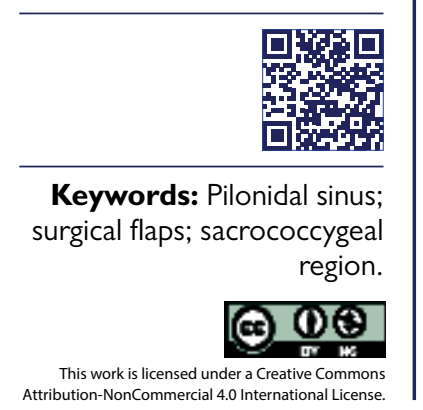

\begin{abstract}
Objective: Various surgical techniques were used to treat advanced sacrococcygeal pilonidal disease. Long learning curve, prolonged surgery and length of hospital stay were observed in most of these methods. In this study, we aimed to present our experience with random pattern rotation flaps in the treatment of sacrococcygeal pilonidal disease with damaged skin structure.
\end{abstract}

Methods: From January 2012 to January 2014, 33 patients were treated with random pattern rotation flaps. Demographic data, body mass index, volume of extracted tissue, width/height ratio of flap, operation time, wound complications and recurrences were evaluated.

Results: Patients were 29 (87.8\%) male and 4 (12.1\%) female with a mean age of 27.8 . The mean operative time was 50.1 minutes and length of hospital stay was 1.3 days. The mean width/height ratio was $0.5 \mathrm{I}$ and most of the patients $(20 / 60.1 \%)$ had a width/height ratio below 0.5 . The mean follow-up period was 54.1 months. Two (6.1\%) patients had a recurrence and wound complications occurred in three $(9.1 \%)$ patients. Most of the patients considered the operation as "good" for both health status and aesthetic satisfaction. Although most of the patients' satisfaction of health status was changed as "excellent" on follow-up after one year, there was no statistically significant difference $(p=0.37)$.

Conclusion: Random pattern rotation flap is a simple solution in the treatment of pilonidal sinus with damaged skin structure. The short learning curve, short operation time, short length of hospital stay and earlier return to work are seen as the advantages.. Further comparative studies are needed to compare health status and aesthetic outcome.

\section{INTRODUCTION}

Sacrococcygeal pilonidal disease (SPD) is a common chronic disorder that usually affects young male population. [l] SPD can be either asymptomatic or complicated. Wide spectrum for the formation of SPD has needed to be classified. ${ }^{[2,3]}$ Various types of classification for SPD defined before and the terms; extensive, complicated, or extended were used to define advanced disease. ${ }^{[4-7]}$ Various minimally invasive and surgical techniques have been described for treatment, but recurrence of SPD is the major obstacle against the ideal approach.

Minimally invasive techniques, such as injection of phenol, fibrin glue, cyanoacrylate inside the sinus cavity, were mostly used in limited disease, and surgical techniques were used to treat advanced disease. ${ }^{[8,9]}$
Sinus removal is the common feature of surgical techniques, whereas the closure of the defect has variations. Flaps are considered as popular treatment modalities and various types of flaps were used for closure of the defect. Commonly used flaps like Karydakis, Limberg, Mutaf, elliptical rotation, $\mathrm{V}-\mathrm{Y}$ advancement were considered for relatively small defects. ${ }^{[10-15]}$ SPD with damaged skin structure can be defined as the formation of granulation tissue with or without ulceration between pits. Damaged skin structure between pits may result with the requirement of large flaps for advanced SPD. Width/height ratio of I:I or 1:2 of the flaps considered above may be inadequate to close the defect. Also, pre-shaped incisions to remove SPD may result in more excision of healthy tissue and larger defect. Rare procedures like bilateral V-Y advancement, perforator based flaps, or bilateral gluteal advancement flaps were 
used for the closure of large defects. ${ }^{[16,17]}$ Long learning curve for experience, prolonged operation and hospitalization time are commonly encountered. Therefore, the requirement of a simple method with similar recurrence and complication rate has been occurred. Use of a random pattern rotation flap with a suitable shape for the defect can be the solution. In this study, we aimed to present our experience with random pattern rotation flaps in the treatment of sacrococcygeal pilonidal disease with damaged skin structure.

\section{MATERIALS AND METHODS}

In this study, patients complaining from SPD with damaged skin structure between sinuses were evaluated for eligibility. Thirty-three patients who received random pattern rotation flap between January 2012-January 2014 were included. The medical records were reviewed retrospectively from our clinic's database that collected prospectively with a followup form including patient characteristics and demographics, body mass index (BMI), the volume of extracted tissue, height of flap, width of the flap, width/height ratio of flap, operation time, time of drain removal, wound complications, recurrences and follow-up time. This study was approved by our hospital ethics committee (reg. 5I4I45I, 2019).

All cases received epidural anesthesia. Prophylactic antibiotics were administered (Cefazoline I gr/IV). The prone position with the hips slightly flexed was preferred method and buttocks were retracted with the help of adhesive bands. The surgical site was cleaned with polyvinyl iodine, at least three times. The incision was marked with borders limited to affected skin either to save healthy tissue or to clean affected area with damaged skin structure. All tissues were excised, and sacrococcygeal fascia was prepared. Height and width were measured from the center of the defect with a ruler. The base of the flap was marked with a measured width. The lateral side of the flap was marked to form a triangle with measured height and then adapted concave to defect. Incisions were deep enough to reach gluteal muscle fascia, and this fascia was released. Adhesive bands were removed following the preparation of flap. I2F suction drain was applied. Separate $2 / 0$ polyglactin sutures were used for approximation of fascia and subcutaneous tissue. Sacrococcygeal fascia was also included in these suture lines to prevent death space. The flap was adapted to defect starting from the base and the side of the defect. $3 / 0$ polypropylene sutures were applied with mattress stitches for skin closure. Following irrigation with saline solution, wounds were cleaned with iodine and dressings were applied.

In the absence of any kind of complication, all patients were discharged on the first day after surgery with drain. Ten days of leave of absence was applied to all cases. Drains were removed when the total amount was below $30 \mathrm{ml} /$ day. Stitches were removed on postoperative day 10. All cases were controlled on the $3^{\text {rd }}, 5^{\text {th }}, 10^{\text {th }}$ day, first month, $6^{\text {th }}$ month and first year. Follow up controls were addressed over the phone. Maceration, discharge, surgical site infection, dehiscence and flap necrosis were considered as wound complications within a one-month period. The only final sign was recorded, even multiple symptoms were seen. A questionnaire, which ranged from I indicating "worse" to 5 indicating "excellent", was applied to compare patients' satisfaction of health status following surgery on postoperative day 30 and one year. The aesthetic satisfaction rate was assessed after a period of six months by asking the patient to give a grade for the operation, regarding the scar and the shape of the buttocks on a scale of "excellent", "good", "fair", "bad" and "worse".

Statistical analysis was carried out using the Statistical Package for Social Sciences software (SPSS Inc., vers. 13.0, Chicago, IL, USA). Numeric values were represented as $\mathrm{n}$, mean \pm standard deviation. Statistical analyzes were calculated with the help of student t-test for evaluation of parametric values. Based on the results of the analysis, the $\mathrm{p}$-value $<0.05$ was considered as statistically significant.

\section{RESULTS}

A total of 623 patients underwent surgery for SPD between January 2012-January 20I4. Thirty-three patients (5.3\%) had SPD with damaged skin structure and were eligible for this study and all eligible patients were included (Table I). Patients were 29 (87.8\%) male and 4 (12.1\%) female with a mean age of $27.8 \pm 6.2$ (within a range of 20 44 ) and a mean body mass index (BMI) of $27.6 \pm 3.3$ (within a range of $20.7-34.1)$. Twelve (36.4\%) patients had a previous operation and three $(9.1 \%)$ patients had previous operations more than once.

The mean operative time was $50.1 \pm 6.8$ (within a range of 43-68) and the mean length of hospital stay was I.3 \pm 0.7 days (within a range of $1-4$ ). The mean width of the flap was $8.05 \pm 1.06 \mathrm{~cm}$ and height of the flap was $16.1 \pm 2.9 \mathrm{~cm}$.

Table I. Characteristics of patients

\begin{tabular}{|c|c|}
\hline Gender (male), n (\%) & $29(87.8)$ \\
\hline Age (years), mean $\pm S D$ & $27.8 \pm 6.2$ \\
\hline BMI $\left(\mathrm{kg} / \mathrm{m}^{2}\right)$, mean $\pm \mathrm{SD}$ & $27.6 \pm 3.3$ \\
\hline Previous operation, n (\%) & $12(36.4)$ \\
\hline Operation time, $(\min \pm S D)$ & $50.1 \pm 6.8$ \\
\hline Length of hospital stay, (day \pm SD) & $1.3 \pm 0.7$ \\
\hline Width: Height ratio of flap, (mean \pm SD) & $0.51 \pm 0.09$ \\
\hline Volume of extracted tissue, $(\mathrm{ml} \pm \mathrm{SD})$ & $138.3 \pm 40.7$ \\
\hline Drain removal, $($ day $\pm S D)$ & $3.4 \pm 0.8$ \\
\hline Wound complication, n (\%) & $3(9.1)$ \\
\hline Infection, n (\%) & I (3.03) \\
\hline Antibiotic requirement, $n$ (\%) & I (3.03) \\
\hline Time for returning to work, $($ day $\pm S D)$ & $11.5 \pm 3.03$ \\
\hline Recurrence, $\mathrm{n}(\%)$ & $2(6.1)$ \\
\hline Mean follow up time, (month $\pm S D)$ & $54.1 \pm 6.5$ \\
\hline
\end{tabular}

Values are presented as mean \pm standard deviation, number (\%). BMI: Body mass index. 
Table 2. Patients health status and aesthetic satisfaction

\begin{tabular}{lccc}
\hline & $\begin{array}{c}\text { PHS PO } \\
\text { day 30 }\end{array}$ & $\begin{array}{c}\text { PHS PO } \\
\text { I year }\end{array}$ & $\begin{array}{c}\text { Aesthetic } \\
\text { outcome }\end{array}$ \\
\hline 5-Excellent & $12(36.4 \%)$ & $18(54.5 \%)$ & $9(27.3 \%)$ \\
4-Good & $15(45.5 \%)$ & $9(27.3 \%)$ & $16(48.5 \%)$ \\
3-Fair & $5(15.1 \%)$ & $5(15.1 \%)$ & $8(24.2 \%)$ \\
2-Bad & I (3\%) & I (3\%) & - \\
I-Worse & - & & - \\
\hline
\end{tabular}

Values are presented as number (\%). PHS: Patients' health status. PO: Postoperative.

The mean width/height ratio was $0.5 \mathrm{I} \pm 0.09$ (within a range of $0.4-0.79)$. Most of the patients $(20 / 60.1 \%)$ had a width/ height ratio below 0.5 . The mean follow-up period was $54.1 \pm 6.5$ months (within a range of $42-65$ ). Two $(6.1 \%)$ patients had a recurrence, on 6th month and second year respectively, within the follow-up period. Patients with recurrence were male and both had wound complications, one patient had an infection with dehiscence and the other patient had discharge on early postoperative period respectively.

Wound complications occurred in three (9.1\%) patients. One patient discharged on postoperative day 7 and conser- vative management with dressings was efficient. One patient had partial dehiscence following infection on postoperative day 7 , wound culture was obtained and five-day antibiotic regimen (ampicillin-sulbactam) was applied without waiting for results. Ampicillin susceptible Escherichia coli was isolated from wound culture and primary repair of dehiscence under local anesthesia was applied on postoperative day 20. Partial flap necrosis-limited in an area of $1.5 \times 1 \mathrm{~cm}$-was occurred on postoperative day 2 in one patient. Resection of affected area and repair with stitches was efficient and the patient was discharged on postoperative day 4 .

Most of the patients considered the operation as "good" for both health status-on postoperative day 30- and aesthetic satisfaction, none of the patients considered the operation as "worse". Although patients' satisfaction of health status was changed on follow-up after I year and most of the patients considered their status of health as "excellent", there was no statistically significant difference $(p=0.37)$. Patients' health status and aesthetic satisfaction results were depicted in Table 2.

\section{DISCUSSION}

Various methods of therapy for SPD can be found in the literature search. The ideal therapy should include a high success rate in healing, low risk of postoperative compli-
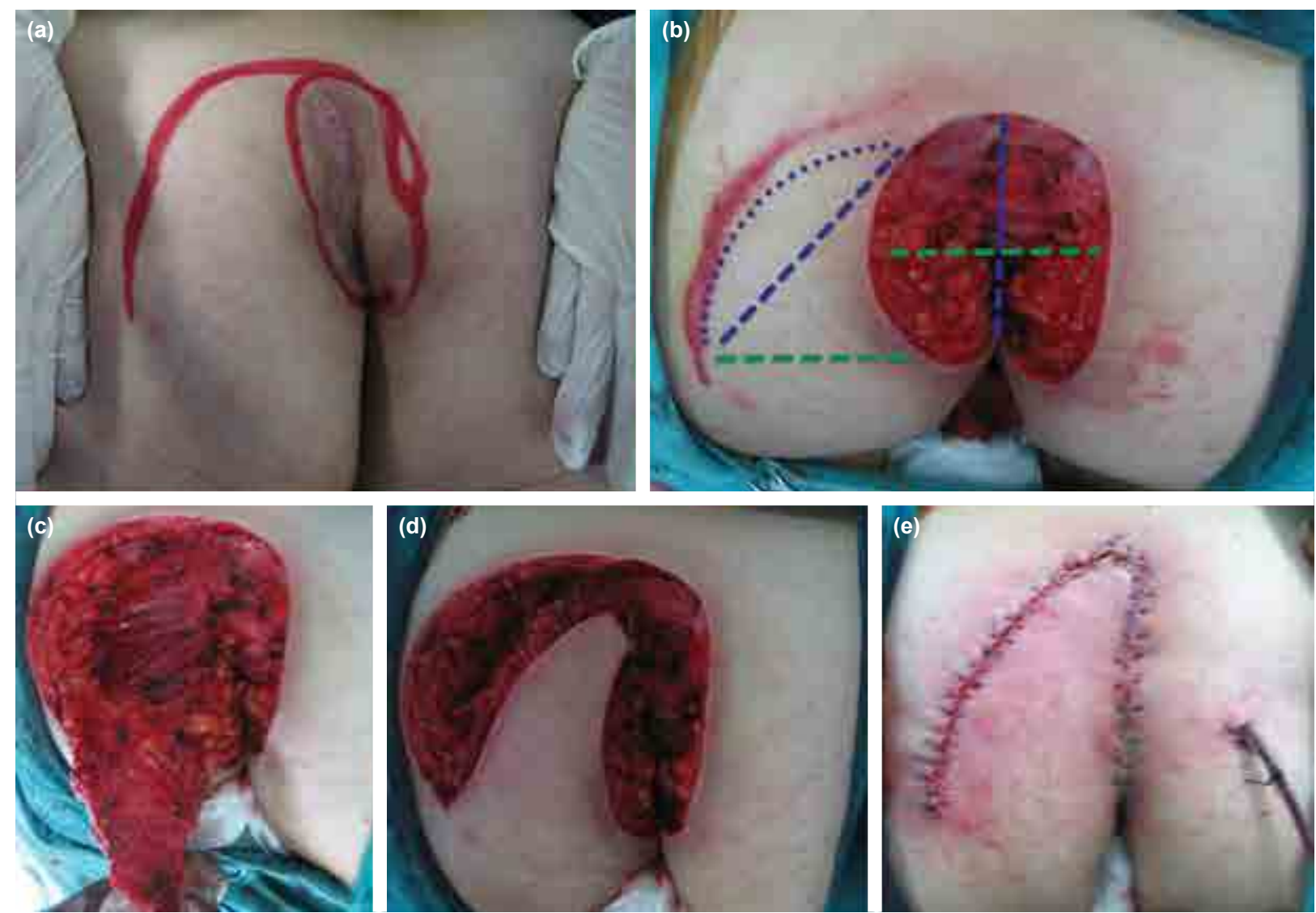

Figure 1. (a) Incision was marked with borders limited to affected skin. (b) Width (green dashed line) was measured for flap's base, height (blue dashed line) was measured to form a triangle with the lateral side of the defect and then adapted concave to defect (blue dots). (c) Preparation of the flap with gluteal muscle fascia. (d) Prepared flap. (e) Closure of the defect. 

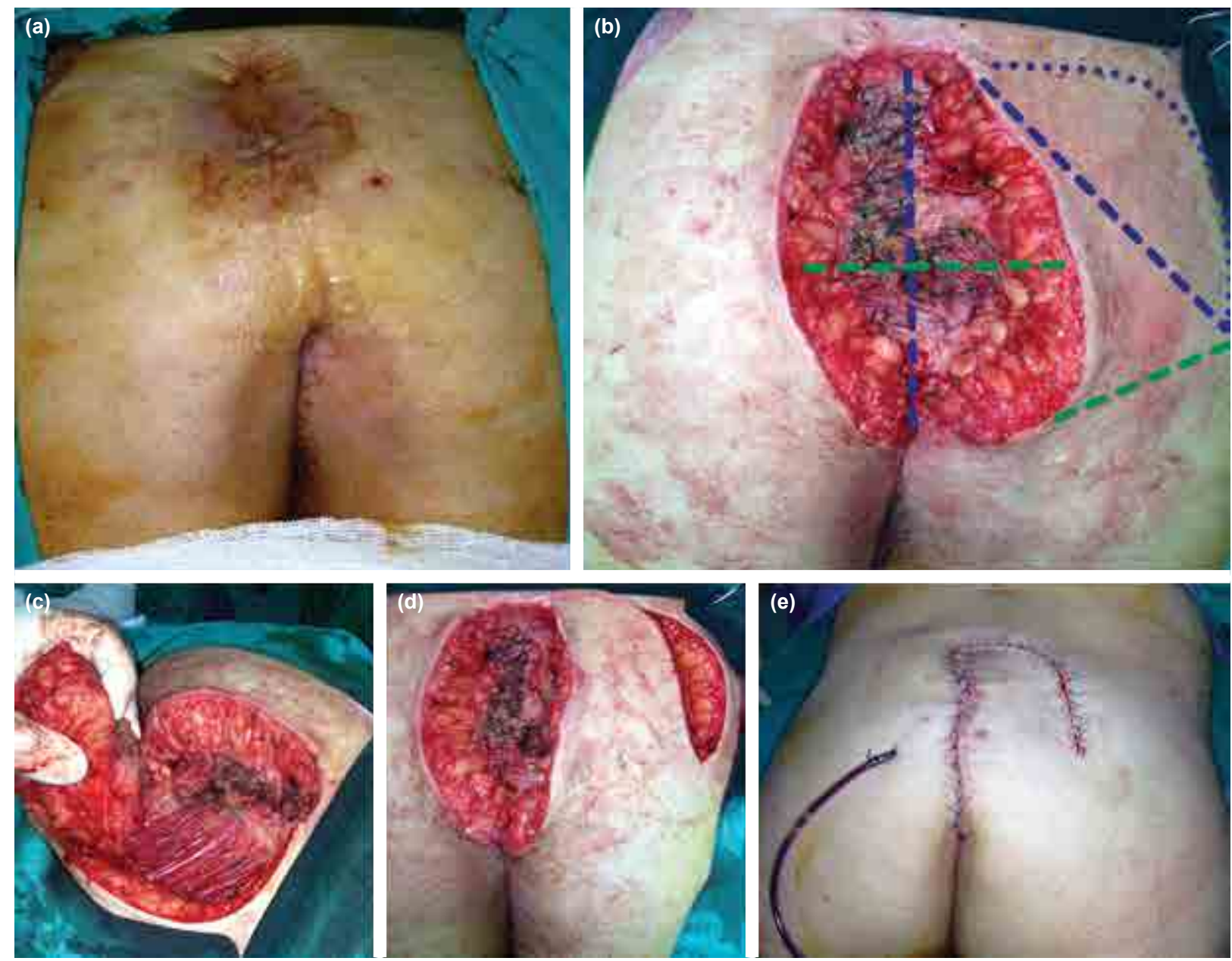

Figure 2. (a) Recurrent sacrococcygeal pilonidal disease. (b) Width (green dashed line) was measured for flap's base, height (blue dashed line) was measured to form a triangle with the lateral side of the defect and then adapted concave to defect (blue dots). (c) Preparation of the flap with gluteal muscle fascia. (d) Prepared flap (e) Closure of the defect.
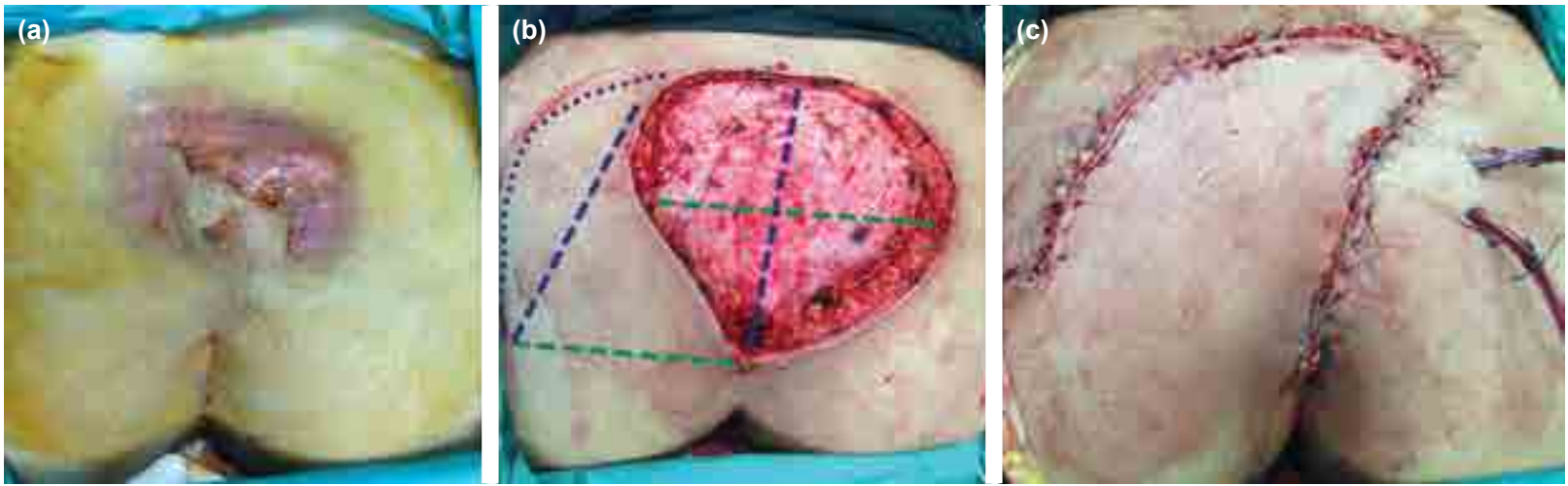

Figure 3. (a) Patient with sacrococcygeal pilonidal disease and hidradenitis suppurativa who refused surgery for 7 years. (b) Width (green dashed line) was measured for flap's base, height (blue dashed line) was measured to form a triangle with the lateral side of the defect and then adapted concave to defect (blue dots). (c) Closure of the defect.

cations, low recurrence rates, decreased hospitalization time, absence of general anesthesia and shorter intervals for returning to work. ${ }^{[1]}$ Minimally invasive techniques were mostly used in limited disease to cover these conditions. ${ }^{[8,9]}$

The definitions extensive, extended, complicated were used in literature to define advanced disease. ${ }^{[4]}$ Treat- ment modalities according to the classification of SPD were revealed for advanced disease. Tezel et al. classified as Type 4 for extensive and Type 5 for recurrent disease and recommended Bascom procedure-combined with separate excision of pits outside the navicular area. ${ }^{[2]}$ Güner et al. classified as Stage 4 for extensive and Stage $\mathrm{R}$ for recurrent disease, rhomboid excision with the Lim- 
berg flap technique was used for Stage 4 and technique was decided based on the potential defect size following excision for Stage R. ${ }^{[3]}$ Pits were used to classify the appearance of SPD for both and damaged skin structure was not evaluated. Although some of the patients with damaged skin structure could be defined as Stage 4 (Fig. I), rhomboid excision may result in unnecessary excision of healthy tissue or Bascom procedure could be inapplicable. Also, a large defect following the excision of recurrent SPD due to damaged skin structure may require a flap with suitable shape (Fig. 2). SPD with hidradenitis suppurativa could be possible and excision of damaged skin structure may require a unique flap for closure (Fig. 3). Therefore, classification systems were partially inadequate to define SPD with damaged skin structure.

Flaps are also commonly applied for closure in our current practice. Commonly used flaps are Karydakis, Limberg, elliptical rotation and Mutaf. ${ }^{[10-15]}$ SPD with damaged skin structure is a rare condition, we saw an incidence of $5.3 \%$ (33/623 patients) in 24 months and commonly used flaps were inapplicable for these patients. Inadequate size of the flap, or unnecessary excision of healthy tissue due to the limits of width/height ratio restricts the use of these flaps. Most of the patients $(20 / 60.1 \%)$ required a flap with a width/height ratio below 0.5 and treated with suitable flap in our series. Bilateral $V-Y$ advancement, gluteal advancement and perforator-based flaps were used for complicated SPD or SPD with recurrence before. ${ }^{[16,17]}$ These procedures are far from being a simple procedure, such as a random pattern rotation flap. Random pattern rotation flaps do not require a long learning curve; it is simple as other pre-shaped rotation flaps. Low rates of seroma formation, wound infection and flap necrosis were defined as advantages of $\mathrm{V}$ - $Y$ advancement flaps. ${ }^{[4,5]}$ Although three patients in our series were affected of these complications, recurrence rates were similar and overall results for operation time $(50.1 \mathrm{~min}$ vs. $70 \mathrm{~min}$, $60 \mathrm{~min}$ ), length of hospital stay ( 1.3 days vs. 3 days), time for returning to work ( I I.5 days vs. within 3 weeks) were better than patients treated with V-Y advancement flaps. The closure is limited with the skin for rotation flaps and our patients were not affected with the feeling of limitation of movement as seen on gluteal advancement flaps. [16] Specific blood supply for flaps can be considered as an advantage against flap necrosis. ${ }^{[17]}$ Although the random pattern and high height ratio, there was only one patient with partial flap necrosis on the distal portion. Resection of affected area and repair with stitches was efficient for the treatment.

Recent studies considered the importance of subjective accounts of health in monitoring medical outcomes. ${ }^{[18]} \mathrm{A}$ visual analog scale (VAS) questionnaire was used to measure the satisfaction rate of health status and aesthetic outcome. Only one of the patients $(3 \%)$ considered the health status as "bad" and none of the patients considered as "worse" on the postoperative day 30 and follow-up on I year. Also, none of the patients considered the operation as "bad" or "worse" for an aesthetic outcome. Positive results could be misleading due to patients' status of health before operation. Most of the patients were suffering from chronic pain, inflammation, discharge and as a result, to stay away from daily activities for years. Therefore, further comparative studies are needed to compare health status and aesthetic outcome.

\section{CONCLUSION}

In conclusion, random pattern rotation flap is a simple solution in the treatment of pilonidal sinus with damaged skin structure. Short learning curve for experience, operation time, length of hospital stay and shorter interval for returning to work are the advantages encountered. Further comparative studies are needed to compare health status and aesthetic outcome.

\section{Ethics Committee Approval}

This study was approved by Dr. Lutfi Kirdar Kartal Training and Research Hospital ethics committee (reg. 5I4I45I, 2019).

\section{Peer-review}

\section{Internally peer-reviewed.}

Authorship Contributions

Concept: H.E.S., K.Ç.; Design: H.E.S., K.Ç.; Supervision: H.E.S., K.Ç.; Fundings: None; Materials: None; Data: H.E.S., K.Ç.; Analysis: H.E.S., K.Ç.; Literature search: H.E.S.; Writing: H.E.S.; Critical revision: K.Ç.

\section{Conflict of Interest}

All authors declare no conflict of interest and all authors have nothing to disclose.

\section{REFERENCES}

1. de Parades V, Bouchard D, Janier M, Berger A. Pilonidal sinus disease. J Visc Surg 2013;150:237-47. [CrossRef]

2. Tezel E. A new classification according to navicular area concept for sacrococcygeal pilonidal disease. Colorectal Dis 2007;9:575-6. [CrossRef]

3. Guner A, Cekic AB, Boz A, Turkyilmaz S, Kucuktulu U. A proposed staging system for chronic symptomatic pilonidal sinus disease and results in patients treated with stage-based approach. BMC Surg 2016;16:18. [CrossRef]

4. Dýlek ON, Bekereciodlu M.Role of simple V-Y advancement flap in the treatment of complicated pilonidal sinus. Eur J Surg 1998;164:961-4. [CrossRef]

5. Berkem H, Topaloglu S, Ozel H, Avsar FM, Yildiz Y, Yuksel BC, et al. V-Y advancement flap closures for complicated pilonidal sinus disease. Int J Colorectal Dis 2005;20:343-8. [CrossRef]

6. Eryilmaz R, Okan I, Coskun A, Bas G, Sahin M. Surgical treatment of complicated pilonidal sinus with a fasciocutaneous V-Y advancement flap. Dis Colon Rectum 2009;52:2036-40. [CrossRef]

7. N N, Kumar M K, Babu K R, Dhanraj P. Tandem rhomboid flap repair: a new technique in treatment of extensive pilonidal disease of the natal cleft. J Clin Diagn Res 2014;8:ND03-4.

8. Girgin M, Kanat BH, Ayten R, Cetinkaya Z, Kanat Z, Bozdağ A, et al. Minimally invasive treatment of pilonidal disease: crystallized phenol and laser depilation. Int Surg 2012;97:288-92. [CrossRef] 
9. Isik A, Eryllmaz R, Okan I, Dasiran F, Firat D, Idiz O, et al. The use of fibrin glue without surgery in the treatment of pilonidal sinus disease. Int J Clin Exp Med 2014;7:1047-51.

10. Zorlu M, Şahiner İT, Zobacı E, Kocak C, Yastı AÇ, Dolapçı M. Early results with the Mutaf technique: a novel off-midline approach in pilonidal sinus surgery. Ann Surg Treat Res 2016;90:265-71. [CrossRef]

11. Neşşar G, Kayaalp C, Seven C. Elliptical rotation flap for pilonidal sinus. Am J Surg 2004;187:300-3. [CrossRef]

12. Dizen H, Yoldas Ö, Yıldız M, Cilekar M, Dilektaşlı E. Modified elliptical rotation flap for sacrococcygeal pilonidal sinus disease. ANZ J Surg 2014;84:769-71. [CrossRef]

13. Omer Y, Hayrettin D, Murat C, Mustafa Y, Evren D. Comparison of modified limberg flap and modified elliptical rotation flap for pilonidal sinus surgery: a retrospective cohort study. Int J Surg 2015;16(Pt A):74-77. [CrossRef]

14. Tokac M, Dumlu EG, Aydin MS, Yalcın A, Kilic M. Comparison of modified Limberg flap and Karydakis flap operations in pilonidal sinus surgery: prospective randomized study. Int Surg 2015;100:870-7. [CrossRef]

15. Altintoprak F, Dikicier E, Arslan Y, Ozkececi T, Akbulut G, Dilek ON. Comparision of the Limberg flap with the V-Y flap technique in the treatment of pilonidal disease. J Korean Surg Soc 2013;85:63-7. [CrossRef]

16. Elalfy K, Emile S, Lotfy A, Youssef M, Elfeki H. Erratum to 'Bilateral gluteal advancement flap for treatment of recurrent sacrococcygeal pilonidal disease: A prospective cohort study' [Int. J. Surg. 29 (2016) 1-8]. Int J Surg 2016;32:189. [CrossRef]

17. Garrido A, Ali R, Ramakrishnan V, Spyrou G, Stanley PR. Reconstruction of the natal cleft with a perforator-based flap. Br J Plast Surg 2002;55:671-4. [CrossRef]

18. Milone M, Musella M, Maietta P, Bianco P, Taffuri C, Salvatore G, et al. Intradermal absorbable sutures to close pilonidal sinus wounds: a safe closure method? Surg Today 2014;44:1638-42. [CrossRef]

\section{Cilt Bütünlüğü Bozulmuş İleri Pilonidal Sinüs Hastalığının Tedavisinde Random Patern Rotasyon Flep Uygulaması}

Amaç: İleri pilonidal sinüs hastalığının tedavisinde çok sayıda cerrahi teknik denenmiştir. Bu yöntemlerin çoğunda uzun öğrenme eğrisi, uzamış ameliyat ve yatış süresi gözlenmiştir. Çalışmamızda cilt bütünlüğü bozulmuş ileri pilonidal sinüs hastalığında random patern rotaston flep deneyimimizi paylaşmayı amaçladık.

Gereç ve Yöntem: Ocak 2012-2014 tarihleri arasında 33 hasta random patern rotasyon flebi ile tedavi edildi. Hastaların demografik özellikleri, beden-kitle indeksi, çıkarılan dokunun hacmi, flep en/boy oranı, ameliyat süresi, yara komplikasyonları ve nüks durumu değerlendirildi.

Bulgular: Hastaların 29'u (\%87.8) erkek ve 4'ü (\% 12.I) kadın, ortalama yaşları ise 27.8'di. Ortalama ameliyat süresi 50.I dakika ve ortalama hastanede kalış süresi 1.3 gündü. Ortalama en-boy oranı 0.5 I'di ve hastaların çoğunluğunda (20/\%60.I) en-boy oranı 0.5 'in altındaydı. Ortalama takip süresi 54.1 ay olarak saptandı. Hastaların çoğu sağık durumu ve estetik memnuniyet açısından ameliyatı "iyi" olarak değerlendirdi. Her ne kadar hastaların büyük kısmında sağık durumu bir yıllık takip süresinden sonra "mükemmel" olarak değerlendirilse de istatistiksel açıdan anlamlı fark saptanmadı $(\mathrm{p}=0.37)$.

Sonuç: Cilt bütünlüğü bozulmuş ileri pilonidal sinüs hastalarında random patern rotasyon flebi basit bir çözüm sunmaktadır. Deneyim kazanmak için kısa öğrenme eğrisi, ameliyat süresi, hastanede kalış süresi ve işe daha erken dönüş avantajları olarak görülmektedir. Sağlık durumu ve estetik memnuniyet açısından gelecekteki karşılaştırmalı çalışmalara ihtiyaç vardır.

Anahtar Sözcükler: Cerrahi flepler; pilonidal sinüs; sakrokoksigeal bölge. 